\title{
PENGARUH MODEL PEMBELAJARAN NUMBERED HEADTOGETHER (NHT) TERHADAP KEMAMPUAN KOMUNIKASI MATEMATIS SISWA DI KELAS VII MTS SWASTA YASPEND MUSLIM PEMATANG TENGAH TAHUN PELAJARAN 2017/2018
}

\author{
${ }^{1}$ R. Maisaroh R. Siregar, S.Pd.I, M.Pd, ${ }^{2}$ Lailan Thawila \\ STKIP Budidaya Binjai \\ 1 maisarohsrg@gmail.com \\ 2lailanthawila1995@gmail.com
}

\begin{abstract}
ABSTRAK
Pengaruh Model Pembelajaran Numbered Head Together Terhadap Kemampuan Komunikasi Matematis Siswa Kelas VII Mts Swasta Yaspend Muslim Pematang Tengah Tahun Pelajaran 2017/2018.

Tujuan penelitian ini untuk mengetahui apakah terdapat pengaruh model pembelajaran Numbered Head Together terhadap kemampuan komunikasi matematis siswa kelas VII MTs Swasta Yaspend Muslim Pematang Tengah tahun pelajaran 2017/2018. Populasi dalam penelitian ini adalah seluruh siswa kelas VII semester ganjil MTs Swasta Yaspend Muslim Pematang Tengah tahun pelajaran 2017/2018 sebanyak 120 siswa yang berdistribusi dalam empat kelas.sampel yang digunakan dalam penelitian ini adalah dua kelas yaitu kelas VII-2 dan VII-4 yang berjumlah 60 siswa. Teknik pengambilan sampel yaitu dengan cara simple random sampling dan diperoleh kelas VII-2 sebagai kelas kontrol dan VII-4 sebagai kelas eksperimen. Jenis penelitian ini adalah quasi eksperimen dengan memberikan perlakuan pada kelompok sample penelitian kemudian diberikan pretes dan postes, sebagai alat pengumpul data digunakan instrumen tes dalam bentuk tes uraian. Dari pengujian hipotesis ternyata $r \neq 0$ dengan demikian dapat disimpulkan bahwa terdapat pengaruh antara model pembelajaran Numbered Head Together dengan kemampuan komunikasi matematis siswa kelas VII semester ganjil MTs Swasta Yaspend Muslim Pematang Tengah tahun pelajaran 2017/2018 hal ini dibuktikan dari hasil pengujian hipotesis pada taraf $\alpha=0,05$ diperoleh nilai $t_{\text {hitung }}=3,012$ kemudian nilai tersebut dibandingkan dengan $t_{\text {tabel }}=1,671$ dengan $\mathrm{n}=30$ dan taraf signifikan 5\%. Karena $t_{\text {hitung }}>\mathrm{t}_{\text {tabel }}$ atau 3,012 > 1,671 maka $\mathrm{H}_{0}$ ditolak dan $\mathrm{H}_{\mathrm{a}}$ diterima.
\end{abstract}

Kata kunci : Model pembelajaran, Numbered Head Together, komunikasi matematis.

\section{Pendahuluan}

Matematika merupakan ilmu yang dinilai sangat penting dan dibutuhkan dalam proses belajar disekolah yang dapat meningkatkan daya fikir perserta didik dengan kemampuan berfikirlogis, kritis, dan kreatif. Hudojo (2003) menyatakan bahwa matematika merupakan suatu alat untuk mengembangkan cara berfikir bersifat abstrak, penalarannya bersifat deduktif dan berkenaan dengan gagasan terstruktur yang hubungan-hubungannya di atur secara logis . Matematika mendasari perkembangan teknolongi dan meningatkan daya fikir manusia, dapat meningkatkan kemampuan berfikir logis, ketelitian dan kesadaran. Oleh karena itu, matematika telah dipelajari mulai dari sekolah rendah (taman kanak-kanak) sampai pada perguruan tinggi.

Peranan penting matematika dalam kehidupan seharusnya membuat matematika menjadi mata pelajaran yang diminati dan menarik. Fakta di lapangan ditemukan banyak siswa kurang menyukai matematika, menganggap sulit dan tidak menarik. Kristina (2007) menyatakan kebanyakan siswa menganggap pelajaran matematika adalah pelajaran yang paling sulit dimengerti, ketidakberhasilan siswa dalam mempelajari 
matematika antara lain adalah siswa belum mampu menangkap konsep atau lambanglambang dengan benar yang sifatnya abstrak. Misalkan pada materi peluang dan permutasi dan kombinasi di kelas XI, mudah menghafal dan mengingat materi tersebut namun sulit memahami serta menerapkan dalam soal berupa pemecahan masalah. Siswa sering menyelesaikan soal dengan menerapkan rumus secara bergantian antara rumus permutasi dengan rumus kombinasi.

$\begin{array}{lcr}\text { Salah satu } & \begin{array}{c}\text { tujuan } \\ \text { adalah } \\ \text { matematika }\end{array} & \begin{array}{r}\text { pembelajaran } \\ \text { mampu }\end{array} \\ \text { mengkomunikasikan } & \text { matematika } & \text { dengan }\end{array}$
gagasan simbol, tabel, diagram atau media lain untuk memperjelas keadaan atau masalah. Kenyataan pembelajaran matematika saat ini hanya berorientasi pada pemberian materi dan soal-soal tanpa meminta siswa untuk mengemukakan pemahamannya secara lisan maupun tulisan. Disini peneliti fokus terhadap komunikasi tulisan (writting) dengan alasan agar siswa mampu mengungkapkan ide matematika dalam fenomena dunia nyata melalui simbol, grafik/gambar, tabel aritmatika sosial ataupun dalam kehidupan sehari-hari.

Komunikasi dalam matematika
berkaitan dengan kemampuan dan
keterampilan siswa dalam berkomunikasi. Abdulhak (dalam Ansari: 2009) mengemukakan standart komunikasi untuk mengukur kemampuan ini adalah: (1) menyatakan ide matematika dengan berbicara, menulis, demonstrasi, dan mengambarkannya dalam bentuk visual, (2) memahami, menginterpretasikan dan menilai ide matematika yang disajikan dalam tulisan lisan atau bentuk visual, (3) menggunkan kosa kata/bahasa, notasi dan struktur matematika untuk menyatakan ide, menggambarkan hubungan, dan pembuatan model. Sementara itu, Kramarski (dalam Ansari: 2009) menyebutkan komunikasi matematis sebagai penjelasan verbal dari penalaran matematis yang diukur melalui tiga dimensi yaitu kebenaran, kelancaran dalam memberikan macam-macam jawaban benar dan representasi matematis, dalam bentuk formal, visual, persaman aljabar dan diagram.

Dari hasil wawancara peneliti dengan salah satu guru bidang studi matematika MTs Swasta Yayasan Pendidikan Muslim Pematang Tengah yaitu Ibu Siti Zahara Fitri S.Pd diperoleh keterangan bahwa kemampuan komunikasi matematis siswa masih sangat rendah. Siswa belum mampu memahami maksud dari soal yang diberikan, siswa belum memahami cara menyelesaikan soal yang diberikan oleh guru. Hal ini menunjukkan bahwa kemampuan komunikasi matematis siswa masih rendah

Untuk itu perlu dicari suatu model pembelajaran yang berpusat pada aktifitas siswa sehingga menciptakan adanya interaksi yang baik antara guru dengan siswa dan siswa dengan siswa serta mampu meningkatkan motivasi siswa. Slavin (2010) mengatakan bahwa pembelajaran kooperatif merupakan model pembelajaran yang telah dikenal sejak lama, dimana pada saat itu guru mendorong para siswa untuk melakukan kerja sama dalam kegiatan-kegiatan tertentu seperti diskusi atau pengajaran oleh teman sebaya. Dalam melakukan proses belajar mengajar guru tidak lagi mendominasi seperti lazimnya pada saat ini, sehingga siswa dituntut untuk berbagi informasi dengan siswa yang lainnya dan saling belajar mengajar sesama mereka.

Salah satu alternatif pembelajaran kooperatif yang dapat meningkatkan kemandirian belajar siswa adalah pembelajaran kooperatif tipe NHT (Numbered Head Together).

Menurut Ibrahim (2000) pembelajaran kooperatif pendekatan struktural NHT dirancang untuk mempengaruhi pola interaksi peserta didik dan memiliki tujuan untuk meningkatkan penguasaan akademik setiap peserta didik. Peserta didik ditempatkan dalam tim belajar beranggotakan 3-5 orang yang merupakan campuran menurut tingkat akademis, jenis kelamin, suku, agama dan 
sebagainya. Kemudian, masing-masing peserta didik dalam setiap tim diberi nomor urut sebagai identitas di dalam timnya. Sehingga nantinya guru dapat memanggil salah satu nomor dan siswa yang memiliki nomor tersebut secara mandiri dan bertanggung jawab untuk menyampaikan hasil diskusi kelompoknya.

Pembelajaran kooperatif tipe NHT adalah suatu model pembelajaran yang lebih memungkinkan siswa untuk lebih aktif dan bertanggung jawab penuh dalam memahami materi pelajaran baik secara berkelompok maupun individual. Dalam pembelajaran kooperatif tipe NHT semua siswa dianggap sama. Guru tidak lagi mendominasi proses pembelajaran dan hanya bertindak sebagai fasilitator. Selama pembelajaran siswa dilibatkan secara langsung sehingga masingmasing siswa memperoleh pengetahuan dan pengalaman belajarnya. Dalam proses pembelajaran kooperatif tipe NHT, siswa aktif bekerja dalam kelompok dan bertanggung jawab penuh terhadap soal yang diberikan.

Berdasarkan dari latar belakang diatas, peneliti merasa tertarik untuk melakukan penelitian dengan judul "Pengaruh Model Pembelajaran Numbered Head Together (NHT) terhadap Kemampuan Komunikasi Matematis Siswa di Kelas VII MTs Swasta Yaspend Muslim Pematang Tengah Tahun Pelajaran 2017/2018”.

\section{METODE}

Populasi dalam penelitian ini adalah seluruh siswa kelas VII MTs Swasta Yaspend Mulim Pematang Tengah Tahun Pelajaran 2017/2018. Dalam penentuan pemilihan sampel ini, teknik sampling yang digunakan adalah Simple Random Sampling. Cara pengambilan sampel dalam penelitian sangatlah penting terlebih jika peneliti ingin hasil penelitiannya berlaku untuk seluruh populasi.

Pengambilan sampel dilakukan dari seluruh populasi yang ada. dalam penelitian ini, pengambilan sampel dilakukan secara acak tanpa memperhatikan strata yang ada dalam populasi itu dengan mengambil 2 kelas dari jumlah keseluruhan kelas yang berjumlah 4 kelas. Sampel dalam penelitian ini berjumlah 60 siswa. Jenis penelitian ini adalah Quasi eksperiment. Dalam penelitian ini, peneliti mengumpulkan data dengan memberikan perlakuan yang berbeda pada dua kelompok sampel penelitian.

Desain penelitian yang digunakan pada Quasi Eksperiment ini adalah Rancangan penelitian control group Pretest-Posttes. Rancangan ini merupakan rancangan penelitian eksperimen yang dilakukan dengan pretest (tes awal) selanjutnya diberi perlakuan dan diakhiri dengan posttest. Instrumen yang digunakan untuk mengumpulkan data adalah dengan memberi tes soal.

\section{HASIL DAN PEMBAHASAN}

\section{a. Hasil Penelitan \\ Data Nilai Pretest Kelas Eksperimen dan Kelas Kontrol}

Pretest adalah soal tes yang diberikan kepada siswa sebelum diberikan perlakuan pembelajaran. Berdasarkan data hasil pretest yang diberikan di kelas eksperimen dan di kelas kontrol, secara ringkas dirangkum pada tabel berikut :

Tabel 1. Data Nilai Pretest Siswa Kelas Eksperimen dan Kelas Kontrol

\begin{tabular}{cccc}
\hline \multicolumn{2}{c}{ Eksperimen } & \multicolumn{2}{c}{ Kontrol } \\
\hline Jumlah Siswa & 30 & Jumlah Siswa & 30 \\
\hline Rata-rata & 29,43 & Rata-rata & 27,6 \\
\hline $\begin{array}{c}\text { Simpangan } \\
\text { Baku }\end{array}$ & 10,17 & $\begin{array}{c}\text { Simpangan } \\
\text { Baku }\end{array}$ & 11,62 \\
\hline Varians & 103,495 & Varians & 135,14 \\
\hline
\end{tabular}

\section{Data Nilai Posttest Kelas Eksperimen dan Kelas Kontrol}

Posttest adalah soal tes yang diberikan kepada siswa setelah diberikan perlakuan pembelajaran. Berdasarkan data hasil posttest yang diberikan di kelas eksperimen dan di kelas kontrol.

Tabel 2. Data Nilai Posttest Siswa Kelas Eksperimen dan Kelas Kontrol 


\begin{tabular}{lclc}
\hline \multicolumn{2}{c}{ Eksperimen } & \multicolumn{2}{c}{ Kontrol } \\
\hline Jumlah Siswa & 30 & Jumlah Siswa & 30 \\
\hline Rata-rata & 75,9 & Rata-rata & 65,26 \\
\hline $\begin{array}{l}\text { Simpangan } \\
\text { Baku }\end{array}$ & \multirow{2}{*}{11,86} & Simpangan & 15,29 \\
\hline Varians & \multirow{2}{*}{140,71} & Vaku & 233,9 \\
\hline
\end{tabular}

Uji normalitas yang digunakan adalah uji Liliefors. Uji Liliefors digunakan untuk mengetahui apakah data berasal dari populasi yang berdistribusi normal atau tidak, dengan ketentuan bahwa data berasal dari populasi yang berdistribusi normal jika memenuhi kriteria $\mathrm{L}_{0}<\mathrm{L}_{\text {tabel }}(0,089<0,161)$ diukur pada taraf signifikansi dan tingkat kepercayaan tertentu. Maka dinyatakan populasi tersebut berdistrubusi normal. Hipotesis yang diajukan dan akan diuji dalam uji normalitas ini sebagai berikut:

Tabel 3. Rekapitulasi Hasil Perhitungan Uji Normalitas dengan Uji liliefors

\begin{tabular}{cccccc} 
Data & $\begin{array}{c}\text { Kelomp } \\
\text { ok }\end{array}$ & $\mathbf{L}_{\mathbf{0}}$ & $\begin{array}{c}\mathbf{L}_{\text {tab }} \\
\text { el }\end{array}$ & $\begin{array}{c}\text { Kesimpu } \\
\text { lan }\end{array}$ & Ket \\
Prete & $\begin{array}{c}\text { Eksperi } \\
\text { men }\end{array}$ & 0.089 & 0,161 & $\begin{array}{c}\text { Terima } \\
\mathrm{H}_{0}\end{array}$ & $\begin{array}{c}\text { Nor } \\
\text { mal }\end{array}$ \\
\cline { 2 - 6 } & Kontrol & 0.156 & 0,1 & Terima & Nor \\
& & 9 & 61 & $\mathrm{H}_{0}$ & mal \\
\hline \multirow{3}{*}{ Postt } & Eksperi & 0.145 & 0,1 & Terima & Nor \\
est & Kontrol & 35 & 61 & $\mathrm{H}_{0}$ & mal \\
\cline { 2 - 6 } & & 35 & 61 & Terima & Nor \\
\hline
\end{tabular}

Uji homogenitas atau uji kesamaan dua varians populasi dilakukan dengan uji Fisher. Untuk kriteria pengujian data kedua sampel adalah homogen jika $\mathrm{F}_{\text {hitung }}<\mathrm{F}_{\text {tabel }}(1,3<1,86)$ pada taraf signifikan 5\%. Maka dinyatakan kedua kelas tersebut homogen.

Tabel 4. Rekapitulasi Hasil Perhitungan Uji Homogenitas dengan Uji Fisher

\begin{tabular}{ccccc}
\hline Data & Kelompok & $\mathbf{F}_{\text {hitung }}$ & $\begin{array}{c}\mathbf{F}_{\text {tab }} \\
\text { el }\end{array}$ & $\begin{array}{c}\text { Kesimpul } \\
\text { an }\end{array}$ \\
\cline { 1 - 2 } Pretest & Eksperimen & \multirow{2}{*}{0,3} & 1,86 & Homogen \\
\cline { 2 - 2 } Postest & Eksperimen & \multirow{2}{*}{1,66} & 1,86 & Homogen \\
\hline
\end{tabular}

Pengujian Hipotesis, Setelah uji prasyarat, maka didapat bahwa kedua kelas berdistribusi normal dan homogen.

\section{a. Uji Hipotesis Model Pembelajaran Kontekstual}

Hipotesis yang akan diuji adalah :

$$
\begin{aligned}
& \mathrm{H}_{0}: \theta_{1}=\theta_{2} \\
& \mathrm{Ha}: \theta_{1} \neq \theta_{2}
\end{aligned}
$$

Hipotesis yang diujikan :

$\mathrm{H}_{0} \quad=$ Tidak terdapat Pengaruh Model Pembelajaran Numbered Head Together (NHT) terhadap Kemampuan Komunikasi Matematis Siswa di Kelas VII MTs Swasta Yaspend Muslim Pematang Tengah Tahun Pelajaran 2017/2018.

$\mathrm{Ha}=$ Terdapat Pengaruh Model Pembelajaran Numbered Head Together (NHT) terhadap Kemampuan Komunikasi Matematis Siswa di Kelas VII MTs Swasta Yaspend Muslim Pematang Tengah Tahun Pelajaran 2017/2018.

Dari hasil perhitungan diperoleh harga $t$ hitung $=3,012$ Dengan taraf signifikan 5\% $(0,05)$ dan dk 58 maka diperoleh $t_{\text {tabel }} 1,671$. Sehingga dapat dilihat $t_{\text {hitung }}>t_{\text {tabel }}$ yaitu 3,012 $>$ 1,671. Maka Ho ditolak. Artinya pada taraf sinifikan 5\% $(0,05)$ terdapat Pengaruh Model Pembelajaran Numbered Head Together (NHT) terhadap Kemampuan Komunikasi Matematis Siswa di Kelas VII MTs Swasta Yaspend Muslim Pematang Tengah Tahun Pelajaran 2017/2018.

\section{SIMPULAN}

Berdasarkan analisis data dan pembahasan maka dapat disimpulkan bahwa Model pembelajaran Numbered Head Together dapat memberikan pengaruh terhadap kemampuan komunikasi matematis siswa kelas VII MTs Swasta Yaspend Muslin Pematang Tengah Tahun Pelajaran 2017/2018 ini ditunjukan dari hasil uji hipotesis. Berdasarkan perhitungan diperoleh $t_{\text {tabel }}=1,671$ dan $t_{\text {hitung }}=3,012$. Karena $t_{\text {hitung }}>t_{\text {tabel }}$ yaitu 3,012 >1,670 maka $\mathrm{H}_{0}$ ditolak dan $\mathrm{H}_{\mathrm{a}}$ diterima.

\section{SARAN}

Berdasarkan kesimpulan diatas dan pengalaman dalam proses belajar mengajar yang terjadi selama penelitian, maka penulis dapat memberikan saran-saran sebagai berikut: 
1. Untuk Guru model pembelajaran Numbered Head Together menjadi salah satu model dan media pembelajaran yang dapat diterapkan dalam proses mengajar.

2. Untuk peneliti selanjutnya penelitian ini hanya fokus pada pokok bahasan bilangan bulat oleh karenanya untuk dapat dikembangkan pada pokok bahasan lainnya.

3. Dengan adanya beberapa keterbatasan dalam melaksanakan penelitian ini, maka sebaiknya dilakukan penelitian lebih lanjut yang meneliti tentang penerapan model pembelajaran Numbered Head Together pada pokok bahasan lain untuk mengukur aspek lain.

\section{DAFTAR PUSTAKA}

Ansari, B. Komunikasi Matematik Konsep dan Aplikasi. Banda Aceh: Yayasan Pena. 2009.

Hudojo, H. Pengembangan kurikulum dan pembelajaran matematika. Malang: Universitas Negeri Malang. 2003

Ibrahim, M.H dkk., Pembelajaran Kooperatif. Universitas Negeri Surabaya, University Press: Surabaya. 2000.

Kristina,Handriani. Meningkatkan Kemampuan Siswa SMA Memahami Konsep Permutasi dan Kombinasi dengan Menggunakan Model Pembelajaran Siklus Belajar (Learnining Cycle). Jurnal ilmiah guru kanderang tigang diterbitkan tahun 2007.

Slavin, E Roberts. Cooperative Learning Teori, Riset, dan Praktik cetakan VIII. Bandung: Nusa Media. 2010 